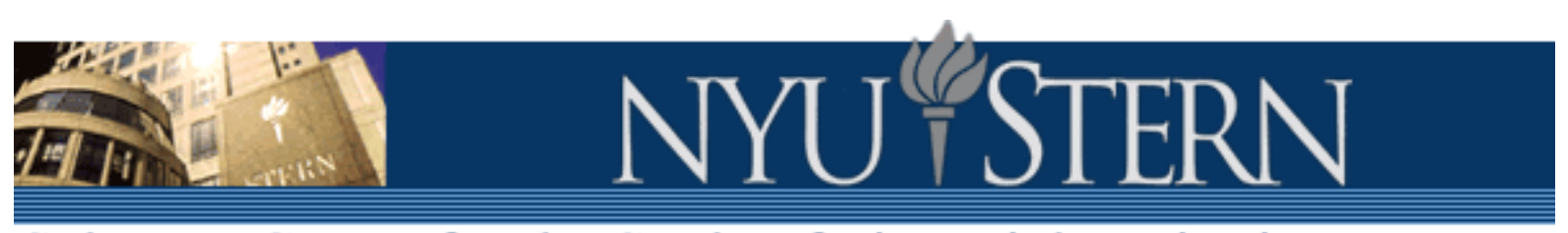

Salomon Center for the Study of Financial Institutions

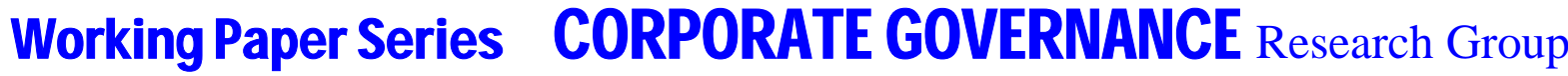

THE IMPACT OF INSTITUTIONAL OWNERSHIP ON CORPORATE OPERATING PERFORMANCE

\author{
Marcia Millon Cornett \\ Alan J. Marcus \\ Anthony Saunders \\ Hassan Tehranian
}

S-CG-03-05 


\title{
The Impact of Institutional Ownership on Corporate Operating Performance
}

\author{
Marcia Millon Cornett* \\ Alan J. Marcus** \\ Anthony Saunders*** \\ Hassan Tehranian****
}

November 7, 2003

The authors are grateful to Ying Duan, Alex Fayman, Victoria Ivashina, and Mark Liu for their research assistance.

*College of Business and Administration, Southern Illinois University, Carbondale, IL 62901. (618) 453-1417; mcornett@cba.siu.edu

** Wallace E. Carroll School of Business, Boston College, Chestnut Hill, MA 02467. (617) 552-2767; alan.marcus@bc.edu

***Salomon Center, Stern School of Business, New York University, New York, 10020. (212) 998-0711; asaunder@stern.nyu.edu

**** Wallace E. Carroll School of Business, Boston College, Chestnut Hill, MA 02467. (617) 552-3944; hassan.tehranian@bc.edu 


\title{
The Impact of Institutional Ownership on Corporate Operating Performance
}

\author{
ABSTRACT \\ This paper examines the relationship between institutional investor involvement \\ in and the operating performance of large firms. We confirm a significant relationship \\ between a firm's operating cash flow returns and both the percent of institutional stock \\ ownership and the number of institutional stockholders. However, the positive \\ relationship between the number of institutional investors holding stock and operating \\ cash flow returns is found only for pressure-insensitive institutional investors (those with \\ no business relationship with the firm). The number of pressure-sensitive institutional \\ investors (those with an existing or potential business relationship with the firm) has no \\ impact on performance. These results suggest that institutional investors that need to \\ protect actual or promote potential business relationships with firms in which they invest \\ are compromised as monitors of the firm, and lend credence to calls for greater \\ independence of board members from firms.
}




\section{The Impact of Institutional Ownership on Corporate Operating Performance}

\section{Introduction}

The spate of corporate scandals in the last five years points to a failure of corporate governance. Many suggestions for reform, reflected for example in the Sarbanes-Oxley Act passed by Congress in 2001 or proposed rules changes at the NYSE and Nasdaq, focus on the quality of monitoring of management decisions. Sarbanes-Oxley, for example, requires independent financial experts to serve on audit committees, and the stock exchanges have called for boards of directors comprised of "independent" agents. These proposals reflect a growing consensus that boards have not been sufficiently diligent in monitoring management, and that they need to be comprised of unaffiliated agents not beholden to management.

On the other hand, institutional investors have become increasingly willing to use their ownership rights to pressure managers to act in the best interest of the shareholders. As these investors have increased their ownership share in firms, there has been an increased focus by regulators and researchers alike on their role in the monitoring, disciplining, and influencing of corporate managers.

A recent set of research studies has found that not all institutional investors are equal [see Hartzell and Starks (2002) and Parrino, Sias, and Starks (2003)]. These papers note that some institutional investors (e.g., banks through their trust departments and insurance companies) have either existing or potential business relationships with firms, and, therefore, in order to protect those relationships might be less willing to challenge management decisions. These investors are labeled pressure-sensitive. In contrast, agents such as investment companies and independent investment advisors do not seek business 
relationships with the firms in which they invest. They are therefore less subject to pressure and accordingly, are better suited to closely monitor, discipline, and impose controls on corporate managers. These institutional investors are labeled pressureinsensitive.

To date, research on the role of institutional investors in corporate monitoring has focused mainly on institutional investor activism (e.g., corporate governance proposals or forced CEO turnover). In contrast, less direct evidence has been presented on the impact of institutional ownership and monitoring on a firm's financial performance, and the results of such studies have been mixed. ${ }^{1}$ In this paper, we look at the relationship between institutional investor involvement (specifically, via stock ownership and board membership) and the operating cash flow returns of firms. We examine whether institutional involvement affects operating cash flow returns as well as how institutional investor monitoring interacts with other corporate governance mechanisms (e.g., director and officer stock ownership, or independent outside directors on boards).

We confirm a positive relationship between measures of institutional investor involvement and a firm's operating cash flow returns. More importantly in light of recent proposals for governance reform, we also demonstrate that the type of institutional investor (pressure-insensitive versus pressure-sensitive) matters. The positive relationship between the number of institutional investors holding stock and operating cash flow returns is found only for pressure-insensitive institutional investors (i.e., those with no business relationship with the

\footnotetext{
${ }^{1}$ Using a group of firms from 1976 and 1986, McConnell and Servaes (1990) find a positive relationship between firm performance as measured by Tobin's q and large blockholder and institutional investor ownership. Agrawal and Knoeber (1996) look at the same relationship for a group of firms from 1987 and find it to be negative.
} 
firm). The number of pressure-sensitive institutional investors (those with an existing or potential relationship with the firm) has no impact on the firm's operating cash flow returns.

These results suggest that institutional investors who are interested in building business relationships with the firms in which they hold stock add little to effective corporate governance and monitoring. When institutional investors are not disinterested agents, their willingness and/or ability to control and discipline management seems to be compromised. This lends weight to calls for greater independence for members of corporate boards.

The rest of the paper is organized as follows. Section 2 discusses the relationship between institutional investor ownership and large firm operating performance and presents our hypotheses. Section 3 discusses other internal corporate governance mechanisms used by firms to influence operating performance which are included as control variables in this study. Section 4 presents information regarding our data and methodology. Section 5 presents empirical results and section 6 concludes the paper.

\section{Institutional Investors and Firm Performance}

A considerable body of research has focused on the role of institutional investors as corporate monitors. The rationale is that due to the high cost of monitoring, only large shareholders such as institutional investors can achieve sufficient benefits to have an incentive to monitor (see, for example, Grossman and Hart, 1980). Indeed, Shleifer and Vishny (1986) note that large shareholders may have a greater incentive to monitor managers than members of the board of directors, who may have little or no wealth invested in the firm. Moreover, large institutional investors have the opportunity, resources, and ability to monitor, discipline, and influence managers. McConnell and 
Servaes (1990), Nesbitt (1994), Smith (1996), and Del Guercio and Hawkins (1999) have found evidence consistent with the hypothesis that corporate monitoring by institutional investors can force managers to focus more on corporate performance and less on opportunistic or self-serving behavior.

On the other hand, Maug (1998) notes that whether institutions use their ability to influence corporate decisions is partially a function of the size of their shareholdings. If institutional investor shareholdings are high, shares are less marketable and are thus held for longer periods. In this case, there is greater incentive to monitor a firm's management. However, when institutional investors hold relatively few shares in a firm, they can easily liquidate their investments if the firm performs poorly, and therefore have less incentive to monitor. Several studies conclude that institutional investors' goal of maintaining the liquidity of their holdings and their desire for short-term profit outweighs the benefits of monitoring management in the hope of eliciting higher long-term profitability [see Coffee (1991), Bhide (1994), Denirag (1998), and Maug (1998)].

On balance, however, it seems clear that large stockholders and institutional investors have become increasingly active in corporate governance, especially in underperforming firms. Bethel et al. (1998) find that block share purchases by institutional investors are most likely in highly diversified firms with poor profitability. Further, these activist purchases are followed by increases in asset divestitures, decreases in mergers and acquisitions, and abnormal share price increases. Gillan and Starks (2000) find that corporate governance proposals sponsored by institutional investors receive more favorable votes than those sponsored by independent individuals or religious organizations. Hartzell and Starks (2002) document a significant positive relationship between concentration of institutional ownership and pay-for-performance sensitivity - particularly when the institutional investors are 
pressure-insensitive - as well as a significant negative relationship between institutional ownership and the level of executive compensation. Chung et al. (2002) find that large institutional shareholdings in a firm deter managers from pursuing opportunistic earnings management through discretionary accrual choices. Finally, Parrino et al. (2003) show that aggregate institutional ownership as well as the number of institutional investors declines in the year prior to forced CEO turnover and that these CEOs are more likely to be replaced with an outsider. Thus, institutional investors can effectively "vote with their feet" when dissatisfied with a firm's management.

In addition to institutional investor activism, a number of papers have looked for a direct impact of institutional investor ownership on firm performance. McConnell and Servaes (1990) find that the percent of institutional investor ownership is significant and positively related to a firm's Tobin's q. Nesbitt (1994), Smith (1996), and Del Guercio and Hawkins (1999) also find a positive relationship between institutional investor ownership and various measures of firm performance. However, Agrawal and Knoeber (1996), Karpoff et al. (1996), Duggal and Miller (1999) and Faccio and Lasfer (2000) find no such significant relationship. Thus, the impact of institutional investor stock ownership on firm performance is still unclear.

This paper adds to the literature on institutional investor ownership and firm performance by examining this relationship for the S\&P 100 firms in the 1990s. Unlike most past research, we measure firm performance using cash flow return on assets and control for other, internal corporate governance mechanisms (discussed below). We also consider several measures of effective institutional investment in the firm: the fraction of institutional investor ownership, the number of institutional owners, membership on the board of directors, and, most significantly, the type of institutional investor. 
The bulk of research examining the impact of institutional investors measures influence solely by their percentage ownership of the firm. Some papers, however, suggest that the number of institutional investors may better capture the impact of such shareholders. These large investors have the incentive to aggressively monitor and weigh in on corporate decisions. Chen et al. (2001) uses the breadth of institutional ownership (the number of mutual funds holding stock in a particular firm) as a predictor of stock returns. Foster and Viswanathan (1996) and Back, Cao, and Willard (1999) show that information on firms is revealed more rapidly when there are greater numbers of informed traders such as institutional investors. Sias et al. (2001) find that stock returns are more strongly related to the number of institutional investors than to the fraction of a firm's shares held by them. And as noted above, Parrino et al. (2003) find that the number of institutional investors in firms is a predictor of impending forced CEO turnovers.

In addition to voicing an opinion through stock ownership, institutional investors sitting on the board of directors have an even more direct opportunity to monitor, discipline, and influence corporate managers. As independent outside directors with their investors' wealth at stake, these institutional investor board members should have a positive impact on the firm's performance.

More recent research on the impact of ownership composition on firm performance has focused on the difference in motivations between various types of institutional investors. This strain of research began with Brickley, Lease, and Smith. (1988) who noted that pressure-insensitive institutional investors are more likely to discipline and/or vote against management than pressure-sensitive ones. Borokhovich et al. (2000) find that the relative holdings of these two groups of institutional investors affect market reaction to announcements of anti-takeover amendments. Hartzell and Starks (2002) show that the 
level of executive pay is negatively related and pay-for-performance is positively related to institutional ownership, but that these relationships are far stronger for pressure-insensitive investors. Given these findings, we look at firm performance as a function of the type of institutional investor (pressure-sensitive versus pressure-insensitive) holding stock in the firm. We hypothesize that the greater the involvement of pressure-insensitive institutional investors, the better the performance of the firm.

\section{Control Variables: Internal Corporate Governance Mechanisms}

Our primary focus is on the impact of institutional ownership on firm performance through its ability to discipline management. However, there are a host of other internal corporate governance mechanisms that also serve to limit managerial discretion and mitigate manager-shareholder conflict. These are necessary control variables for our analysis. Internal corporate governance variables that have been examined in other contexts include director and executive officer stock ownership, board of director characteristics, $\mathrm{CEO}$ age and tenure, and CEO pay-for-performance sensitivity. We discuss these in turn.

\subsection{Director and Executive Officer Stock Ownership}

Several studies argue that stock and/or option ownership by board members and executive officers gives them an incentive monitor managers carefully to ensure that the firm is run efficiently (see for example Brickley, Lease, and Smith, 1988). The impact of their decisions on their own personal wealth is compounded when the potential receipt of additional stock or options is a component of the compensation package. Consequently, they are less likely to take actions that would reduce shareholder wealth. Thus, the higher 
the stock ownership of directors and executive officers, the better should be the firm's operating performance.

\subsection{Board of Director Characteristics}

\subsubsection{Percent of Independent Outside Directors on the Board}

There is a considerable literature regarding the effect of the composition of the board of directors (i.e., inside versus outside directors). Boards dominated by outsiders are arguably in a better position to monitor and control managers (Dunn, 1987). Outside directors are independent of the firm's managers, and in addition bring a greater breadth of experience to the firm [see Firstenberg and Malkiel (1980) and Vance (1983)]. Weisbach (1988), Byrd and Hickman (1992) and Bhagat, Brickley and Coles (1994) show that outside dominated boards are, in fact, more likely than inside-dominated boards to respond to poor performance by replacing the CEO. A number of studies have linked the proportion of outside directors to financial performance and shareholder wealth [see Brickley, Coles and Terry (1994), Byrd and Hickman (1992), Subrahmanyan, Rangan, and Rosenstein (1997), and Rosenstein and Wyatt (1990)]. These studies consistently find better stock returns and operating performance when outside directors hold a significant percentage of board seats.

\subsubsection{CEO/Chair Duality}

In about 80 percent of companies in the U.S., the CEO is the chairman of the board (Lorsch and MacIver, 1978). CEO/Chair duality concentrates power in the CEO, potentially making disagreement on the part of outsiders costlier, which can exacerbate potential conflicts 
of interest. The dual office structure also permits the CEO to effectively control information available to other board members and thus impede effective monitoring (Jensen, 1993).

\subsubsection{Board Size}

Jensen (1993) argues that small boards are more effective in monitoring a CEO's actions, as large boards have a greater emphasis on "politeness and courtesy" and are therefore easier for the CEO to control. Yermack (1996) finds an inverse relationship between board size and Tobin's q in a sample of industrial companies, and concludes that large boards are less effective than small boards. These studies suggest that the size of a firm's board is inversely related to firm operating performance.

\subsection{Age and Tenure of CEO}

The age and tenure of the CEO may determine his or her effectiveness in managing the firm. Some studies suggest that top officials with little experience have limited effectiveness because it takes time to gain an adequate understanding of the company [Bacon and Brown (1973) and Alderfer (1986)]. In fact, increased experience has been linked to resistance to paying greenmail (Kosnik 1987, 1990) as well as to better financial performance (Brown and Maloney, 1998). These articles suggest that the older or the longer the tenure of the firm's CEO, the greater the understanding of the firm and its industry, and the better the performance of the firm.

\subsection{CEO's Pay-Performance Sensitivity}

The relationship between managerial compensation and shareholder wealth is welldocumented. For example, Jensen and Murphy (1990a) find that CEO wealth increases by 
$\$ 3.25$ per $\$ 1,000$ increase in shareholder wealth. Jensen and Murphy (1990b) argue that the level of pay alone is not important in resolving the agency issues between the CEO and the firm's shareholders. Rather, the strength of the pay-performance relationship is the key to mitigating agency problems.

There are several mechanisms that link pay to performance. They can be classified into salary and bonus, stock options, and performance-based dismissal actions. ${ }^{2}$ Accordingly, we use three measures of CEO's incentive-based pay: the dollar value of a CEO's total compensation (salary and bonus, options, stock grants, long-term incentive plan payouts, and others), the dollar value of stock options granted to the CEO, and the ratio of the dollar value of stock options granted to the dollar value of total compensation. This last measure implicitly assumes that the sensitivity of option value to operating performance is substantially greater than the sensitivity of salary and bonus. Both Jensen and Murphy (1990a) and Hubbard and Palia (1995) present evidence supporting this notion.

\subsection{Data and Methodology}

We examine the impact of institutional investor ownership on firm performance and the relative impact of pressure sensitive versus insensitive institutional investors over the period 1993 through 2000. Our sample is the firms in the S\&P 100 (obtained from

\footnotetext{
${ }^{2}$ Studies of performance-based dismissal actions such as Coughlan and Schmidt (1985), Warner, Watts and Wruck (1988), Weisbach (1988), Jensen and Murphy (1990a) and Murphy and Zimmerman (1991) have found a negative relationship between net-of-market firm performance and the probability of managerial turnover. These findings suggest that managers are more likely to leave after bad years than after good years and are disciplined by a credible threat of dismissal. As this issue is not the focus of our study, we do not include the threat of dismissal in our definition of incentive-based pay.
} 
Standard \& Poor's) as of November $1993 .^{3}$ Eleven of the 1993 S\&P 100 firms were eventually acquired by other firms over the eight-year sample period and are dropped from the analysis in the year of the merger. Another nine firms were lost by the year 2000 due to the unavailability of proxy or institutional investor ownership data. Firms that were dropped from the S\&P 100 between 1994 and 2000, but that remained publicly traded and continued to operate, remain in the sample. After these adjustments to the data, we are left with a sample of 737 firm-years.

Following Healy et al. (1992), who examine performance of firms after mergers, operating performance is measured as operating cash flow return on assets (i.e., annual earnings before interest and taxes plus depreciation divided by total assets at the end of the year), which we denote ROA. This measure of performance is effectively independent of firm leverage. ROA also offers advantages over Tobin's $q$ as a measure of firm performance. Whereas Tobin's q reflects growth opportunities (and, more generally, expectations of the firm's prospects in future years) through the impact of these factors on market value, cash flow return on assets is a more focused measure of current performance. The financial statement data needed to calculate ROA were obtained from the Compustat database for each year, 1993-2000.

Both levels and changes in ROA may be affected by extraneous industry effects. Therefore, we measure firm performance in each year by its industry-adjusted ROA (IAROA), i.e. as firm cash-flow return on assets minus industry-average cash-flow return on assets in that year. Industry-adjusted comparisons allow us to examine firm-specific performance irrespective of any industry-wide factors that may affect ROA. We define the

\footnotetext{
${ }^{3}$ We use S\&P 100 firms because of the high likelihood that they are considered for investment by institutional investors.
} 
industry comparison group for each firm as all firms listed on Compustat with the same 3digit SIC code. ${ }^{4}$ The number of firms in each industry comparison group ranges from a minimum of 1 to a maximum of 356 . Industry ROA is calculated as the total-asset weighted average ROA of all firms in the industry.

Institutional investor ownership data for the period 1993-2000 were obtained from the CDA Spectrum data base, which compiles holdings of institutional investors from 13-f filings. ${ }^{5}$ Institutional investors file their holdings as the aggregate investment in each firm regardless of the number of individual fund portfolios they manage.

Our measures of institutional investor ownership follow those used in Hartzell and Starks (2002). We calculate both the proportion of total institutional investor ownership and the proportion of ownership accounted for by the top five institutional investors in each firm. Further, as discussed above, recent research finds that the type of institutional investor affects corporate monitoring. Specifically, pressure-insensitive investment companies and independent investment advisors may be better monitors. Accordingly, using the Brickley et al. (1988) and Hartzell and Starks (2002) classifications, we use CDA Spectrum coding to divide the data on institutional investor ownership into two subgroups: pressure-insensitive institutional investors, which are taken to be investment companies and independent investment advisors (primarily pension fund advisors), versus pressuresensitive institutional investors, which are comprised of bank trust departments and insurance companies. To be conservative, we group institutional investors that CDA classifies as "other" (for example, endowment funds) with the pressure sensitive group.

\footnotetext{
${ }^{4}$ We remove all sample firms from any industry comparison groups. For example, General Motors and Ford (both S\&P 100 firms) are not included in any industry comparison groups.

${ }^{5}$ Institutional investors with more than $\$ 100$ million invested in equities of any firm must report this equity ownership quarterly to the SEC in $13-f$ filings.
} 
Thus, from the CDA Spectrum data base we collect the following information for each firm for each year over the period 1993-2000: total shares outstanding, number of shares owned by all institutional investors, number of shares owned by the top five institutional investors, number of shares owned by investment companies and independent investment advisors (pressure-insensitive institutional investors), number of shares owned by banks, insurance companies, and others (pressure-sensitive institutional investors), and the number of pressure-insensitive, pressure-sensitive, and all institutional investors holding shares in each firm.

Finally, as discussed above, several studies have found that CEO compensation, board composition, and director and executive officer stock ownership affect a firm's performance. Accordingly, we use proxy statements for each year 1993-2000 to obtain the percent of director and officer stock ownership, board size, percent of independent outsiders on the board, ${ }^{6,7} \mathrm{CEO} /$ chair duality, $\mathrm{CEO}$ age, $\mathrm{CEO}$ tenure, and $\mathrm{CEO}$ compensation (salary, bonus, options, stock grants, long-term incentive plan payouts, and other).

Table 1 presents descriptive statistics for the sample. While mean ROA is 19.03 percent, ${ }^{8}$ mean industry-adjusted ROA is, as expected, nearly zero, 0.68 percent. Thus, the sample firms perform just a bit better than their industry competitors. The industryadjusted ROA ranges from -40.55 percent to 38.31 percent.

\section{INSERT TABLE 1 HERE}

\footnotetext{
${ }^{6}$ Specifically, independent outside directors are directors listed in proxy statements as managers in an unaffiliated non-financial firm, managers of an unaffiliated bank or insurance company, retired managers of another company, lawyers unaffiliated with the firm, and academics unaffiliated with the firm.

${ }^{7}$ We also collected and analyzed data on affiliated outside directors on the board. Results including affiliated and independent outside directors do not differ from those using only independent outside directors. Thus, we do not report results for the combined measure.

${ }^{8}$ Recall that this is a cash flow ROA, which includes depreciation as well as net income in the numerator.
} 
On average, 413 institutional investors, of which 240 are pressure-sensitive and 173 are pressure-insensitive, held stock in each firm in our sample. Institutional ownership is significant, averaging 59.3 percent of the outstanding shares in each firm. ${ }^{9}$ The percent of shares held ranges from a low of 16.6 percent to a high of 85.8 percent. The top-five institutional investors alone own on average 20.1 percent of total shares of each firm. Pressure-sensitive institutional investors own, on average, 34.1 percent of total shares, while pressure-insensitive institutional investors hold, on average, 25.3 percent of total shares. In contrast, directors and executive officers hold, on average, only 3.6 percent of the outstanding shares in their firms.

While institutional investors hold a large fraction of outstanding shares, they do not often sit on the board of directors. On average the boards of directors seat 12.4 members. Less than one of these are filled by representatives of either pressure-insensitive (0.36) or pressure-sensitive (0.43) institutional investors. Instead, these seats are filled by, on average, 2.4 inside directors, 1.64 affiliated outside directors, and 8.33 independent outside directors. The maximum number of institutional investors on the board is 5 . Thus, the majority of the directors are independent outsiders (albeit not institutional investors).

The average age of the firms' CEOs is 57 years (ranging from 39 to 74) and, on average, the CEOs have been in place for just over seven years (ranging from 1 to 39). These CEOs are paid an average of $\$ 2.337$ million in salary and bonus annually and another $\$ 4.096$

\footnotetext{
${ }^{9}$ This is the mean value of the percentage ownership averaging across all firms in all years, not the aggregate value of institutional holdings divided by the total value of all firms in the sample.
} 
million in options. ${ }^{10} \mathrm{CEO}$ compensation from all sources averages $\$ 8.39$ million. Averaging across CEOs, 37.1 percent of total compensation is comprised of options.

\subsection{Methodology}

We estimate multivariate regressions in which the firm's industry-adjusted ROA in each year is a function of the explanatory variables in the following list. The observations across firms are pooled in one regression. There are 737 observations, one for each firmyear. ${ }^{11}$ Variations of the following equation are estimated:

$$
\begin{aligned}
\mathrm{IAROA}_{i t}= & a_{1}+b_{1} \mathrm{FIISOWN}_{i t}+b_{2} \ln \left(\mathrm{NII}_{i t}\right)+b_{3} \ln \left(\mathrm{NIIOB}_{i t}\right)+b_{4} \mathrm{FIIOB}_{i t}+ \\
& b_{5} \mathrm{DOSOWN}_{i t}+b_{6} \mathrm{FINDDIR}_{i t}+b_{7} \mathrm{CEOCHD}_{i t}+b_{8} \ln \left(\mathrm{BRDSZE}_{i t}\right)+ \\
& b_{9} \ln \left(\mathrm{CEOAGE}_{i t}\right)+b_{10} \ln \left(\mathrm{CEOTEN}_{i t}\right)+b_{11} \mathrm{CEOCOMP}_{i t}+e_{i t}
\end{aligned}
$$

where variable definitions are given in the following table (see next page).

\section{Regression Results}

Table 2 presents regression results using the full sample of institutional investors, both pressure-insensitive and pressure-sensitive. Seven specifications are presented, differing by the measure of institutional ownership employed and the measure of CEO compensation.

\section{INSERT TABLE 2 HERE}

\footnotetext{
${ }^{10}$ Following Hartzell and Starks (2001), we measure option value using the dividend-adjusted Black-Scholes formula. This is a superior measure of ex ante value to option compensation given in the proxy statement, which reflects exercises in any year. In any case, the two measures are highly correlated in our sample.

${ }^{11}$ In the regression analysis below, we trim extreme data points, eliminating the top and bottom one percent of observations for each right-hand side variable. Therefore, the number of data points in our regressions is somewhat less than 737 .
} 


\begin{tabular}{|c|c|c|}
\hline Explanatory variable & Symbol & Variations employed in regression analysis \\
\hline $\begin{array}{l}\text { Fraction of shares of the } \\
\text { firm owned by } \\
\text { institutional investors }\end{array}$ & FIIOWN & $\begin{array}{l}\text { - fractional ownership of all institutional investors } \\
\text { - fractional ownership of top } 5 \text { institutional investors } \\
\text { - fractional ownership of pressure-insensitive institutional } \\
\text { investors } \\
\text { - fractional ownership of pressure-sensitive institutional } \\
\text { investors }\end{array}$ \\
\hline $\begin{array}{l}\text { natural log of the } \\
\text { number of institutional } \\
\text { investors holding stock } \\
\text { in firm }\end{array}$ & $\ln (\mathrm{NII})$ & $\begin{array}{l}\text { - number of all institutional investors holding stock } \\
\text { - number of pressure-insensitive institutional investors } \\
\text { holding stock } \\
\text { - number of pressure-sensitive institutional investors } \\
\text { holding stock }\end{array}$ \\
\hline $\begin{array}{l}\text { natural log of the } \\
\text { number of institutional } \\
\text { investors on the board of } \\
\text { directors }\end{array}$ & $\ln (\mathrm{NIIOB})$ & $\begin{array}{l}\text { - total number of institutional investors on the board } \\
\text { - number of pressure-insensitive institutional investors on } \\
\text { the board } \\
\text { - number of pressure-sensitive institutional investors on } \\
\text { the board }\end{array}$ \\
\hline $\begin{array}{l}\text { fraction of board of } \\
\text { directors comprised of } \\
\text { institutional investors }\end{array}$ & FIIOB & $\begin{array}{l}\text { - fraction of board of directors comprised of all } \\
\text { institutional investors } \\
\text { - fraction of board of directors comprised of pressure- } \\
\text { sensitive institutional investors } \\
\text { - fraction of board of directors comprised of pressure- } \\
\text { insensitive institutional investors }\end{array}$ \\
\hline $\begin{array}{l}\text { fraction of board of } \\
\text { directors comprised of } \\
\text { independent outside } \\
\text { directors }\end{array}$ & FINDDIR & \\
\hline $\begin{array}{l}\text { fraction of shares in firm } \\
\text { owned by directors and } \\
\text { officers }\end{array}$ & DOSOWN & \\
\hline $\begin{array}{l}\text { CEO/Chair duality } \\
\text { dummy: equals } 1 \text { if the } \\
\text { CEO is also the chair of } \\
\text { the board of directors, } \\
\text { and } 0 \text { otherwise }\end{array}$ & CEOCHD & \\
\hline $\begin{array}{l}\text { natural log of the size of } \\
\text { the board of directors }\end{array}$ & $\ln (\mathrm{BRDSIZE})$ & \\
\hline $\begin{array}{l}\text { natural log of the CEO's } \\
\text { age }\end{array}$ & $\ln (\mathrm{CEOAGE})$ & \\
\hline $\begin{array}{l}\text { natural log of the CEO's } \\
\text { tenure }\end{array}$ & $\ln ($ CEOTEN) & \\
\hline CEO's compensation & $\ln (\mathrm{CEOCOMP})$ & $\begin{array}{l}\text { - natural log of CEO total compensation } \\
\text { - natural log of CEO compensation in the form of options } \\
\text { - CEO compensation in the form of options/total } \\
\text { compensation }\end{array}$ \\
\hline
\end{tabular}


Regression 1 in Table 2 examines the dependence of industry-adjusted ROA on the percent of shares owned by all institutional investors, the number of institutional investors holding stock in the firm, the number of institutional investors with seats on the board of directors, and the percent of the board of directors comprised of institutional investors. The coefficient on the percent of shares owned by all institutional investors is positive (.0117) but significant at only the 10 percent level $(\mathrm{t}=1.86)$. Moreover, the economic impact of percentage institutional ownership is relatively modest. The regression coefficient implies that an increase of one (sample) standard deviation in institutional ownership (i.e., using Table 1, an increase in fractional ownership of 0.143 or 14.3 percentage points) would increase industry-adjusted ROA by only 0.00167 , or 0.167 percent.

The log of the number of institutional investors holding stock in the firm is far more influential on ROA. Its coefficient is positive (0.0194) and significant at better than the 1 percent level $(\mathrm{t}=3.76)$. A one standard deviation increase in institutional investors starting from the mean level of 413 (i.e., an increase from 413 to 659 ) increases $\ln$ (institutional investors) by .467 and therefore increases ROA by $.467 \times .0194=.0091$ or 0.91 percent, which is more than five times the impact of the one standard deviation increase in institutional stock ownership. Such a contribution to ROA, nearly one percent, is a first-order economic impact. These results confirm that higher institutional investment is in fact associated with improved operating performance, consistent with the notion that institutional ownership results in better monitoring of corporate managers. The higher statistical and economic significance of the number of institutional investors holding stock compared to the percent of institutional ownership suggests that it is not so much the 
fraction of shares held by institutional investors that affects a firm's performance, but the number of such investors. ${ }^{12}$

The coefficients on the number of institutional investors on the board and the percent of institutional investors on the board are insignificant. However, given that so few representatives of institutional investors sit on boards of directors, it is not surprising that we find no significance for these variables.

Notice also the control variables in regression 1 . The coefficient on the fractional stock ownership of directors and executive officer, 0.0734 , is insignificant $(t=1.36)$. This result is contrary to many previous papers. However, when stock ownership by institutional investors is high, giving these investors a strong incentive to monitor, share ownership by directors and executive officers may on the margin be less important and contribute less to incremental firm performance.

The coefficient on the percent of the board comprised of outside directors, 0.0699 , is positive and significant at the 1 percent level $(t=3.15)$. Thus, increasing the percent of independent directors (with their ability to monitor and control managers) appears to align the interests of managers and shareholders, thereby reducing agency conflicts and resulting

\footnotetext{
${ }^{12}$ In principle, additional numbers of institutional investors might help or hinder monitoring. More investors increase the number of potential monitors and the collective power of outsider investors to influence management. However, at some point, additional investors might create a free-rider problem in which each investor hopes that another one will bear the costs of monitoring. Our sample shows little evidence of this potential problem. This is evident from the high significance of the total number of investors in explaining industry-adjusted ROA. It also is evident from Regressions 4 and 5 (see discussion below), which replace the share ownership of all institutional investors with the share ownership of only the top-five investors. If the free-rider problem were severe, one would expect this latter variable to better predict firm performance, since it looks at the collective holding of only a relatively small group of institutional investors for which the free-rider problem would be mitigated. However, as we discuss shortly, top-five ownership and total ownership are virtually interchangeable in our regressions.
} 
in higher ROA. Other characteristics of the board of directors have no significant impact on industry-adjusted ROA. The coefficients on the $\mathrm{CEO}$ /Chair duality dummy, board size, and CEO age and tenure are all insignificant.

Finally, in regression 1 the coefficient on the log of the CEO's total compensation is negative, -.0069 and significant at the 1 percent level $(t=-3.01)$, implying that higher CEO compensation is associated with lower industry-adjusted ROA. As noted above, Jensen and Murphy (1990b) suggest that the level of pay alone is not important in resolving the agency issues between the CEO and the firm's shareholders. ${ }^{13}$ Instead, what is crucial is the strength of the pay-for-performance relationship. Thus, rather than CEO total compensation, regressions 2 and 3 use respectively the natural log of CEO option compensation and option compensation as a fraction of total compensation. The coefficients on both of these measures of CEO compensation are positive $(0.0225$ and 0.1099 , respectively) and significant at better than the 1 percent level $(t=7.93$ and 8.76, respectively). Higher $\mathrm{CEO}$ compensation paid in the form of options reliably predicts higher industry-adjusted ROA.

The economic impact of option-based compensation is dramatic. An increase of one sample standard deviation in option compensation from a starting point at the sample average would increase option-based compensation by a factor of 1.40 , and $\ln$ (compensation) by .336 ; this would imply an increase in ROA of $.336 \times .0225=.0076$ or 0.76 percent. An increase of one sample standard deviation in option-based compensation as a fraction of total compensation (i.e., an increase of .255 or 25.5 percentage points) increases ROA by $.255 \times .1099=.0280$ or 2.80 percent, a startlingly large impact. Note

\footnotetext{
${ }^{13}$ In fact, "excessive" executive pay might signify inadequate corporate governance, which would induce a negative empirical relationship between total pay and firm performance.
} 
also that when options to total compensation is used as the measure of CEO compensation (regression 3) the coefficient on the percent of shares owned by all institutional investors increases to .00185 , and attains significance at the 1 percent level $(t=2.76)$. Further, the adjusted R-squared statistic for this regression, 42.2 percent, is considerably higher than for other specifications.

The results for the control variables are consistent across all of the OLS regressions reported in Tables 2 through 4.

Regressions 4 and 5 replace the percent of shares owned by all institutional investors on the right-hand side with percentage ownership of the top five institutional investors. This group has the greatest amount of wealth at stake and therefore, the greatest incentive to monitor. The coefficients on top-five ownership are positive in both specifications (.0389 and .0375 , respectively). While these are more than double the corresponding coefficients on total institutional ownership in Regressions 2 and 3, the average value of top-five ownership is less than half that of total institutional ownership, so the increment to ROA attributable to institutional ownership is actually quite comparable regardless of which measure is employed, as are the t-statistics on the coefficients. Moreover, the other regression coefficients and R-square statistics are barely affected by the choice of top-five versus total ownership. We conclude that these two measures of stock ownership are essentially interchangeable, at least in this context, and henceforth report only regressions using share ownership of all institutional investors.

Regressions 6 and 7 split the number of institutional investors holding stock in each firm into two components, the number of pressure-insensitive and pressure-sensitive investors respectively. (Like the other regression pairs, 6 and 7 differ in the measure of CEO compensation; the log of dollar value of options is used in regression 6 , while the 
ratio of option to total compensation is used in regression 7.) Interestingly, when the number of institutional investors is split in this manner, only the pressure-insensitive investors seem to matter. In regression 6 , the coefficient on this variable is $0.0159(\mathrm{t}=$ 2.76) and in regression 7 it is $0.0126(t=2.69)$. In contrast, the coefficients on the number of pressure-sensitive institutional investors are effectively zero, -.0052 and 0.0014 respectively, with t-statistics below 0.4 . Thus, it appears that only the number of pressureinsensitive institutional investors seem to induce improved performance, consistent with the hypothesis that pressure-sensitive institutional investors, who risk damaging business relationships with firms in which they hold stock if they vote against management, are less effective at taking actions that increase ROA.

To further explore the difference between the impact of pressure-insensitive and pressure-sensitive institutional investors, we estimate variants of the specifications in Table 2. In Table 3, we re-estimate Regressions 2 and 3 from Table 2, but we split the right-hand side institutional investor variables into their exclusively pressure-insensitive or exclusively pressure-sensitive components. Regressions 1 and 2 in Table 3 use only pressure-insensitive institutions on the right-hand side, regressions 3 and 4 use only pressure-sensitive institutions, while regressions 5 and 6 include both types of institutions, but allow different coefficients for each. (Regressions 2 and 3 in Table 2 in effect impose the constraint that these coefficients be equal.)

\section{INSERT TABLE 3 HERE}

Regressions 1 and 2 in Table 3 show results for the impact of pressure-insensitive investors on industry-adjusted ROA. Similar to Regressions 2 and 3 in Table 2, these two specifications differ only in the measure of CEO compensation used. Broadly speaking, 
these regression results are highly similar to their Table 2 counterparts (Regressions 2 and 3). The coefficients on fraction of shares owned by pressure-insensitive investors are positive, both 0.0135 , both significant at better than the 10 percent level, and both roughly the same magnitude as the coefficients on total institutional ownership in Table 2. The number of pressure-insensitive institutional investors remains most significant in explaining industry-adjusted ROA. The coefficients on this variable are 0.0155 and 0.0132 respectively, both of which are significant at better than the 1 percent level, and both nearly equal to their corresponding values in the Table 2 regressions. Board membership by this pressure-insensitive group is again insignificant, most likely due to the fact that these institutional investors seldom sit on the boards of directors in which they own stock. Thus, again, the number of institutional investors holding stock, more so than the percent of stock owned by institutional investors, seems to most reliably predict firm performance.

Regressions 3 and 4 in Table 3 repeat Regressions 1 and 2, but use pressuresensitive rather than pressure-insensitive investors as explanatory variables. While the coefficients on percent of shares owned by this group are nearly identical to those on pressure-insensitive ownership (.0124 here versus .0135 in Regressions 1 and 2), the coefficients on the number of pressure-sensitive institutional investors are far smaller than in the regressions for pressure-insensitive investors. The coefficients on this variable in Regressions 3 and 4 are .0012 and .0030 respectively, compared to .0155 and .0132 in Regressions 1 and 2), and are no longer significant. Thus, while the fraction of shares owned by pressure-sensitive institutional investors still seems to matter, the number of these institutions investing in the firm does not affect performance.

Finally, Regressions 5 and 6 in Table 3 allow separate coefficients on both pressure-sensitive and pressure-insensitive variables. Confirming the results in 
Regressions $1-4$, the overwhelming pattern is that pressure-sensitive ownership variables are irrelevant. Even share ownership of this group, which was marginally significant in Regression 3 and 4, now has a t-statistic well below 1. In contrast, both the coefficient and significance of share ownership of pressure-insensitive investors noticeably increase in this specification compared to the others, as do the coefficients on option compensation. It appears that the impact of institutional investors on ROA documented in Table 2 is in fact due to the pressure-insensitive subgroup.

In Table 4, we investigate potential interactions between the right-hand side variables. In light of the preceding discussion, we use variations of Regressions 1 and 2 from Table 3, which employ only pressure-insensitive institutions as explanatory variables. As there, the two regressions in Table 4 differ only in the measure of option-based compensation. We find substantial evidence of complementarity among several of these variables with respect to their impact on industry-adjusted ROA. The coefficients on the interaction of share ownership of pressure-insensitive institutions with director and executive ownership, with independent outside board membership, and with option compensation are all positive, and all significant at either a 5 percent or 1 percent level. The interaction term between option compensation and the number of pressure-insensitive investors is likewise positive and significant at a 1 percent level. This is true whether one measures option compensation in dollar terms or as a fraction of total compensation.

One might interpret these positive interactions as evidence that the actions of each monitor are more effective when the other potential monitors are "on the same page." A "coalition of value maximizers" might be formed of (pressure-insensitive) institutional investors, outside directors, and managers with steep pay-for-performance compensation. The actions of each are more effective when the others pull in the same direction. 
Interestingly, the coefficients on the other key explanatory variables increase substantially when the interaction terms are added to the right-hand side. The coefficients on both fractional ownership of pressure-insensitive investors as well as the number of such investors are much higher in these interaction regressions than they are in the corresponding Regressions 1 and 2 of Table 3. However, the overall explanatory power of the interaction regressions in Table 4 as measured by R-square is no higher than that of the Table 3 regressions.

\section{Conclusions}

Institutional investors are the majority owners of most large corporations in the U.S. These investors have been increasingly willing to use their ownership rights to pressure firm managers to act in the best interest of the shareholders.

The results presented in this paper confirm a relationship between institutional investor involvement in a firm and its operating cash flow returns. Specifically, we find a significant positive relationship between the percent of institutional stock ownership and operating cash flow returns and, even more strongly, between the number of institutional investors holding stock in a firm and operating cash flow returns. However, the positive relationship between the number of institutional investors holding stock and operating cash flow returns is found only for pressure-insensitive institutional investors (those with no business relationship with the firm). The number of pressure-sensitive institutional investors (those with an existing or potential relationship with the firm) in a firm has no impact on operating cash flow returns, suggesting that these institutional investors are compromised as monitors by their interests in protecting business relationships with the firm. We also find that institutional investors rarely hold seats on the boards of the firms 
in which they invest. Thus, at least in our sample, this type of involvement by institutional investors has no measurable impact on a firm's operating cash flow returns. 


\section{REFERENCES}

Agrawal, A., and C.R. Knoeber, 1996. Firm performance and mechanisms to control agency problems between managers and shareholders. Journal of Financial and Quantitative Analysis 31, 377-397.

Alderfer, C.P., 1896. The invisible director on corporate boards. Harvard Business Review 64, 38-52.

Back, K.H., H.H. Cao, and G.A. Willard, 2000. Imperfect competition among informed traders. Journal of Finance 55, 2117-2155.

Bacon, J., and J.K. Brown, 1973. Corporate Directorship Practices: Role, Selection and Legal Status of the Board. The Conference Board, New York.

Bethel, J., J. Liebiskind, and T. Opler, 1998. Block share purchases and corporate performance. Journal of Finance 53, 605-635.

Bhagat, S., J.A. Brickley, and J.L. Coles, 1994. The costs of inefficient bargaining and financial distress: Evidence from corporate lawsuits. Journal of Financial Economics 35, 221-247.

Bhide, A., 1994. Efficient markets, deficient governance: U.S. securities regulations protect investors and enhance market liquidity. But do they alienate managers and shareholders? Harvard Business Review 72, 128-140.

Borkhovich, K., K. Brunarski, and R Parrino, 2000. Variation in the monitoring incentives of outside blockholders. Cleveland State University, Miami University, and University of Texas Working Paper.

Brickley, J.A., J.L. Coles, and R.L. Terry, 1994. Outside directors and the adoption of poison pills. Journal of Financial Economics 35, 371-390.

Brickley, J., R. Lease, and C. Smith, 1988. Ownership structure and voting on antitakeover amendments. Journal of Financial Economics 20, 267-292.

Brown, W., and M.T. Maloney, 1992. Acquisition performance and corporate board composition. Clemson University Working Paper

Bryd, J., and K. Hickman, 1992. Do outside directors monitor managers? Evidence from tender offer bids. Journal of Financial Economics 32, 195-222.

Chen, J., J. Hong, and J. Stein, 2001. Breadth of ownership and stock returns. NBER Working Paper.

Chung, R., M. Firth, and J. Kim, 2002. Institutional monitoring and opportunistic earnings management. Journal of Corporate Finance 8, 29-48. 
Coffee. J., 1991. Liquidity versus control: The institutional investor as corporate monitor. Columbia Law Review 91, 1277-1368.

Coughlan, A.T., and R.M. Schmidt, 1985. Executive compensation, management turnover and firm performance. Journal of Accounting and Economics 7, 43-66.

Del Guercio, D., and J. Hawkins, 1999. The motivation and impact of pension fund activism. Journal of Financial Economics 52, 293-340.

Demirag, I.S., 1998. Corporate governance, accountability, and pressure to reform: An international study. JAI Press, Stamford, CT.

Duggal, R., and J.A. Millar, 1999. Institutional ownership and firm performance: The case of bidder returns. Journal of Corporate Finance 5, 103-117.

Dunn, D.J., 1987. Directors aren't doing their jobs. Fortune (March), 117-119.

Faccio, M., and M.A. Lasfer, 2000. Do occupational pension funds monitor companies in which they hold large stakes? Journal of Corporate Finance 6, 71-110.

Foster, D.F., and S. Viswanathan, 1996. Strategic trading when agents forecast the forecasts of others. Journal of Finance 51, 1437-1478.

Firstenberg, P.B., and B.G. Malkiel, 1980. Why corporate boards need independent directors. Management Review (April), 26-38.

Gillan, S., and L. Starks, 2000. Corporate governance proposals and shareholder activism: The role of institutional investors. Journal of Financial Economics 57, 275-305.

Grossman, S. and O. Hart, 1980. Takeover bids, the free rider problem, and the theory of the corporation. Bell Journal of Economics 11, 42-64.

Hartzell, J.C., and L.T. Starks, 2002. Institutional investors and executive compensation. Working paper.

Healy, P.M., K.G. Palepu, and R.S. Ruback, 1992. Does corporate performance improve after mergers? Journal of Financial Economics 31(2), 135-175.

Hubbard, G.R., and D. Palia, 1995. Executive pay and performance evidence from the US banking industry. Journal of Financial Economics 39, 105-130.

Jensen, M., 1993. The modern industrial revolution, exit, and the failure of internal control systems. Journal of Finance 48, 831-880.

Jensen, M. and K. Murphy, 1990a. Performance pay and top-management incentives. Journal of Political Economy 98, 225-264. 
Jensen, M., and K. Murphy, 1990b. CEO incentives it's not how much you pay, but how. Journal of Applied Corporate Finance 3, 36-49.

Karpoff, J.M., P.H. Malatesta, and R.A. Walkling, 1996. Corporate governance and shareholder initiatives: Empirical evidence. Journal of Financial Economics 42, 365-395.

Kosnik, R.D., 1987. Greenmail: A study of board performance in corporate governance. Administrative Science Quarterly 32, 163-185.

Kosnik, R.D., 1990. Effects on board demography and directors' incentives on corporate greenmail. Academy of Management Journal 33, 129-150.

Lorsch, , J. W. and E. MacIver, 1978, Pawns or Potentates: The Reality of America's Corporate Board. Cambridge, MA. Harvard Business School Press.

Maug, E., 1998. Large Shareholders as Monitors: Is there a trade-off between liquidity and control? Journal of Finance 53, 65-98.

McConnell, J.J., and H. Servaes, 1990. Additional evidence on equity ownership and corporate value. Journal of Financial Economics 27, 595-612.

Murphy, K.J. and J.L. Zimmerman, 1991. Financial performance over CEO careers: An empirical Investigation. University of Rochester Working Paper.

Nesbitt, S.L., 1994. Long-term rewards from shareholder activism: a study of the 'CalPERS effect.' Journal of Applied Corporate Finance 6, 75-80.

Parrino, R., R.W. Sias, and L.T. Starks, 2003. Voting with their feet: Institutional ownership changes around forced CEO turnover. Journal of Financial Economics $68,3-46$.

Rosenstien, S., and J.G. Wyatt, 1990. Outside directors, board independence, and shareholder wealth. Journal of Financial Economics 26, 175-191.

Shleifer, A. and R. Vishny, 1986. Large shareholders and corporate control. Journal of Political Economy 94, 461-448.

Sias, R., L. T. Starks, and S. Titman, 2001. The price impact of institutional trading. Washington State University and University of Texas at Austin Working Paper.

Smith, M., 1996. Shareholder activism by institutional investors: Evidence from CalPERS. Journal of Finance 51, 227-252.

Subrahmanyan, V., N. Rangan, and S. Rosenstein, 1997. The role of outside directors in bank acquisitions. Financial Management 26, 23-36. 
Wahal, S. and J. J. McConnell, 2000. Do institutional investors exacerbate managerial myopia? Emory University and Purdue University Working Paper.

Warner, J.B., R.L. Watts, and K.H. Wruck, 1988. Stock prices and top management changes. Journal of Financial Economics 20, 461-492.

Weisbach, M.S., 1988. Outside directors and CEO turnover. Journal of Financial Economics 20, 431-460.

Yermack, D., 1996. Higher market valuation of companies with a small board of directors. Journal of Financial Economics 40, 185-211. 


\section{Table 1}

\section{Descriptive Statistics on Institutional Investors Involvement in S\&P 100 Firms over the Period 1993-2000}

ROA is annual operating cash flow return on assets (earnings before interest and taxes plus depreciation over a year divided by total assets at the end of the year). Financial statement data needed to calculate ROA are obtained from the Compustat data base for each year, 1993-2000. For each S\&P 100 firm, we classify industry comparison firms as all firms listed on Compustat with the same 3-digit SIC code. Industry-adjusted ROA is then measured as a sample firm's ROA minus the (total asset) weighted average industry ROA. Data on institutional investor ownership for the period 1993-2000 are obtained from the CDA Spectrum data base. These data include total shares outstanding, number of shares owned by all institutional investors, number of shares owned by the top five institutional investors, number of shares owned by investment companies and independent investment advisors (pressure-insensitive institutional investors), number of shares owned by banks, insurance companies, and others (pressure-sensitive institutional investors), and the number of pressure-insensitive, pressure-sensitive, and all institutional investors. We use proxy statements for the sample firms for each year 1993-2000 to collect data on the fraction of director and officer stock ownership, board size, the fraction of independent outsiders on the board, CEO/chair duality, CEO age, CEO tenure, and CEO compensation (salary, bonus, options, stock grants, long-term incentive plan payouts, and others). The sample size is 737 .

\begin{tabular}{lccccc}
\hline Variable & Mean & Median & $\begin{array}{c}\text { Standard } \\
\text { Deviation }\end{array}$ & Minimum & Maximum \\
\hline ROA & .1903 & .1856 & .0915 & -.1910 & .5443 \\
$\begin{array}{l}\text { Industry-adjusted } \\
\text { ROA }\end{array}$ & .0068 & .0034 & .0806 & -.4055 & .3831 \\
$\begin{array}{l}\text { Fraction of shares } \\
\text { owned by institutional } \\
\text { investors }\end{array}$ & & & & & \\
\end{tabular}

Fraction of shares owned by top five institutional investors

Fraction of shares owned by

pressure-sensitive

institutional investors

Fraction of shares owned by

pressure-insensitive

institutional investors

Number of institutional investors

Number of pressure-sensitive institutional investors

Number of pressure-insensitive institutional investors

Number of 


\begin{tabular}{|c|c|c|c|c|c|}
\hline on the board & .36 & 0 & .605 & 0 & 3 \\
\hline $\begin{array}{l}\text { Number of } \\
\text { pressure-sensitive } \\
\text { institutional investors } \\
\text { on the board }\end{array}$ & .43 & 0 & .66 & 0 & 5 \\
\hline $\begin{array}{l}\text { Fraction director } \\
\text { plus executive officer } \\
\text { stock ownership }\end{array}$ & .036 & .014 & .063 & .0003 & .408 \\
\hline $\begin{array}{l}\text { Number of } \\
\text { inside directors }\end{array}$ & 2.40 & 2 & 1.57 & 1 & 10 \\
\hline $\begin{array}{l}\text { Number of } \\
\text { affiliated outside } \\
\text { directors }\end{array}$ & 1.64 & 1 & 1.51 & 0 & 8 \\
\hline $\begin{array}{l}\text { Number of } \\
\text { independent outside } \\
\text { directors }\end{array}$ & 8.33 & 8 & 2.29 & 1 & 16 \\
\hline $\begin{array}{l}\text { Fraction of independent } \\
\text { outside directors }\end{array}$ & .677 & .692 & .152 & .143 & .929 \\
\hline Board size & 12.4 & 12 & 2.5 & 6 & 22 \\
\hline CEO age (years) & 57.0 & 57 & 5.1 & 39 & 74 \\
\hline CEO tenure (years) & 7.1 & 5 & 6.8 & 1 & 39 \\
\hline $\begin{array}{l}\text { CEO salary and bonus } \\
\text { (in } \$ \text { thousands) }\end{array}$ & 2,337 & 1,801 & 2,027 & 372 & 19,484 \\
\hline $\begin{array}{l}\text { CEO options } \\
\text { (in } \$ \text { thousands) }\end{array}$ & 4,096 & 1,611 & 11,989 & 0 & 201,406 \\
\hline $\begin{array}{l}\text { CEO total } \\
\text { compensation } \\
\text { (in } \$ \text { thousands) }\end{array}$ & 8,390 & 4,798 & 15,229 & 512 & 230,034 \\
\hline $\begin{array}{l}\text { Options as a } \\
\text { fraction of total } \\
\text { CEO compensation }\end{array}$ & .371 & .358 & .255 & 0 & .957 \\
\hline
\end{tabular}


Table 2

Regression Results Using All Institutional Investors Involvement in S\&P 100 Firms Over the Period $1993-2000$

Variations of the following regressions are estimated.

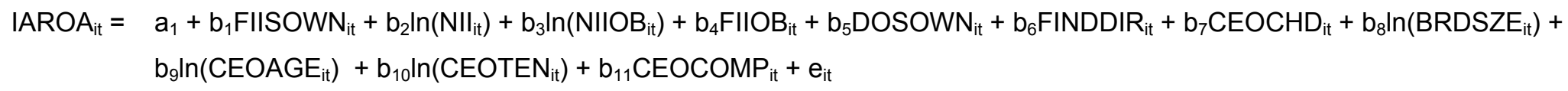

where IAROA $A_{i t}=$ industry-adjusted ROA for firm i in year t, FIISOWN = fraction institutional investor stock ownership in firm i in year t, (variations include: fraction total institutional investor stock ownership and fraction of top-5 institutional investor stock ownership), $\mathrm{NII}_{\mathrm{it}}=$ the number of institutional investors holding stock in the firm, (variations include: total number of institutional investors holding stock, number of pressure-insensitive institutional investors holding stock, number of pressure-sensitive institutional investors holding stock), $\mathrm{NIIOB}_{\text {it }}=$ number of institutional investors on the board of directors of the firm, $\mathrm{FIOB}_{\mathrm{it}}=$ fraction of institutional investors on the board of directors, $\mathrm{DOSOWN}_{\mathrm{i}}=$ the fraction of director and officer stock ownership, FINDDIR $_{\mathrm{it}}=$ the fraction of independent outside directors on the board, $C E O C H D_{\text {it }}=$ dummy variable equal to 1 if the CEO is also the chair of the board

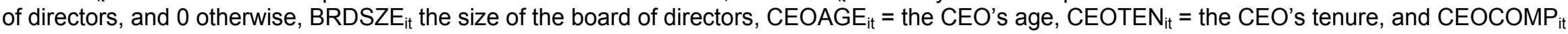
= CEO's compensation, (variations include: natural log of total compensation, natural log of option compensation, ratio of option to total compensation). t-values are in parentheses.

\begin{tabular}{|c|c|c|c|c|c|c|c|}
\hline Variable & $\begin{array}{c}\text { Regression } \\
1\end{array}$ & $\begin{array}{c}\text { Regression } \\
2 \\
\end{array}$ & $\begin{array}{c}\text { Regression } \\
3 \\
\end{array}$ & $\begin{array}{c}\text { Regression } \\
4 \\
\end{array}$ & $\begin{array}{c}\text { Regression } \\
5 \\
\end{array}$ & $\begin{array}{c}\text { Regression } \\
6 \\
\end{array}$ & $\begin{array}{c}\text { Regression } \\
7 \\
\end{array}$ \\
\hline Intercept & $\begin{array}{l}-0.0474 \\
(-0.93)\end{array}$ & $\begin{array}{l}-0.1125 \\
(-0.65)\end{array}$ & $\begin{array}{l}-0.0658 \\
(-0.41)\end{array}$ & $\begin{array}{l}-0.1177 \\
(-0.68)\end{array}$ & $\begin{array}{l}-0.0705 \\
(-0.44)\end{array}$ & $\begin{array}{l}-0.0980 \\
(-0.57)\end{array}$ & $\begin{array}{l}-0.0590 \\
(-0.37)\end{array}$ \\
\hline $\begin{array}{l}\text { Fraction of shares } \\
\text { owned by all } \\
\text { institutional investors }\end{array}$ & $\begin{array}{l}0.0117 \\
(1.86)^{*}\end{array}$ & $\begin{array}{l}0.0120 \\
(1.91)^{*}\end{array}$ & $\begin{array}{l}0.0185 \\
(2.76)^{\star \star \star}\end{array}$ & - & - & $\begin{array}{l}0.0109 \\
(1.73)^{*}\end{array}$ & $\begin{array}{l}0.0117 \\
(1.84)^{*}\end{array}$ \\
\hline $\begin{array}{l}\text { Fraction of shares } \\
\text { owned by top five } \\
\text { institutional investors }\end{array}$ & - & - & - & $\begin{array}{r}0.0389 \\
(2.45)^{\star \star}\end{array}$ & $\begin{array}{r}0.0375 \\
(2.33)^{\star \star}\end{array}$ & - & - \\
\hline $\begin{array}{l}\text { In(Number of } \\
\text { institutional investors) }\end{array}$ & $\begin{array}{c}0.0194 \\
(3.76)^{* * *}\end{array}$ & $\begin{array}{r}0.0148 \\
(2.46)^{* *}\end{array}$ & $\begin{array}{c}0.0141 \\
(2.76)^{\star * *}\end{array}$ & $\begin{array}{r}0.0149 \\
(2.47)^{* *}\end{array}$ & $\begin{array}{c}0.0141 \\
(2.76)^{\star * *}\end{array}$ & - & - \\
\hline $\begin{array}{l}\text { In(Number of } \\
\text { pressure-insensitive } \\
\text { institutional investors) }\end{array}$ & - & - & - & - & - & $\begin{array}{c}0.0159 \\
(2.76)^{\star \star \star}\end{array}$ & $\begin{array}{c}0.0126 \\
(2.69)^{\star * *}\end{array}$ \\
\hline
\end{tabular}




\begin{tabular}{|c|c|c|c|c|c|c|c|}
\hline $\begin{array}{l}\text { In(Number of } \\
\text { pressure-sensitive } \\
\text { institutional investors) }\end{array}$ & - & - & - & - & - & $\begin{array}{l}-0.0052 \\
(-0.14)\end{array}$ & $\begin{array}{l}0.0014 \\
(0.39)\end{array}$ \\
\hline $\begin{array}{l}\text { In(Number of } \\
\text { institutional investors } \\
\text { on board) }\end{array}$ & $\begin{array}{l}-0.0038 \\
(-0.02)\end{array}$ & $\begin{array}{l}-0.0064 \\
(-0.31)\end{array}$ & $\begin{array}{l}-0.0106 \\
(-0.55)\end{array}$ & $\begin{array}{l}-0.0064 \\
(-0.31)\end{array}$ & $\begin{array}{l}-0.0107 \\
(-0.56)\end{array}$ & $\begin{array}{l}-0.0061 \\
(-0.30)\end{array}$ & $\begin{array}{l}-0.0108 \\
(-0.57)\end{array}$ \\
\hline $\begin{array}{l}\text { Fraction of board } \\
\text { comprised of } \\
\text { institutional investors }\end{array}$ & $\begin{array}{l}0.1291 \\
(0.53)\end{array}$ & $\begin{array}{l}0.1919 \\
(0.75)\end{array}$ & $\begin{array}{l}0.2450 \\
(1.03)\end{array}$ & $\begin{array}{l}0.1916 \\
(0.75)\end{array}$ & $\begin{array}{l}0.2451 \\
(1.03)\end{array}$ & $\begin{array}{l}0.1860 \\
(0.73)\end{array}$ & $\begin{array}{l}0.2468 \\
(1.03)\end{array}$ \\
\hline $\begin{array}{l}\text { Fraction of firm owned } \\
\text { by directors plus } \\
\text { executive officer }\end{array}$ & $\begin{array}{l}0.0734 \\
(1.36)\end{array}$ & $\begin{array}{l}0.0791 \\
(1.41)\end{array}$ & $\begin{array}{l}0.0769 \\
(1.42)\end{array}$ & $\begin{array}{l}0.0792 \\
(1.42)\end{array}$ & $\begin{array}{l}0.0771 \\
(1.42)\end{array}$ & $\begin{array}{l}0.0765 \\
(1.37)\end{array}$ & $\begin{array}{l}0.0740 \\
(1.36)\end{array}$ \\
\hline $\begin{array}{l}\text { Fraction of board } \\
\text { comprised of independent } \\
\text { outside directors }\end{array}$ & $\begin{array}{c}0.0699 \\
(3.15)^{\star \star \star}\end{array}$ & $\begin{array}{c}0.0704 \\
(2.95)^{\star \star \star}\end{array}$ & $\begin{array}{c}0.0694 \\
(3.12)^{\star * *}\end{array}$ & $\begin{array}{c}0.0701 \\
(2.93)^{\star * \star}\end{array}$ & $\begin{array}{c}0.0691 \\
(3.11)^{\star \star \star}\end{array}$ & $\begin{array}{c}0.0704 \\
(2.95)^{\star * *}\end{array}$ & $\begin{array}{c}0.0702 \\
(3.15)^{\star * \star}\end{array}$ \\
\hline CEO duality dummy & $\begin{array}{l}-0.0075 \\
(-0.85)\end{array}$ & $\begin{array}{l}-0.0121 \\
(-1.31)\end{array}$ & $\begin{array}{l}-0.0083 \\
(-0.93)\end{array}$ & $\begin{array}{l}-0.0121 \\
(-1.31)\end{array}$ & $\begin{array}{l}-0.0083 \\
(-0.93)\end{array}$ & $\begin{array}{l}-0.0117 \\
(-1.27)\end{array}$ & $\begin{array}{l}-0.0081 \\
(-0.91)\end{array}$ \\
\hline In(Board size) & $\begin{array}{l}-0.0021 \\
(-1.34)\end{array}$ & $\begin{array}{l}-0.0319 \\
(-1.55)\end{array}$ & $\begin{array}{l}-0.0148 \\
(-0.76)\end{array}$ & $\begin{array}{l}-0.0319 \\
(-1.54)\end{array}$ & $\begin{array}{l}-0.0147 \\
(-0.75)\end{array}$ & $\begin{array}{l}-0.0310 \\
(-1.50)\end{array}$ & $\begin{array}{l}-0.0137 \\
(-0.70)\end{array}$ \\
\hline In(CEO age) & $\begin{array}{l}0.0364 \\
(0.55)\end{array}$ & $\begin{array}{l}0.0410 \\
(1.01)\end{array}$ & $\begin{array}{l}0.0179 \\
(0.48)\end{array}$ & $\begin{array}{l}0.0422 \\
(1.04)\end{array}$ & $\begin{array}{l}0.0190 \\
(0.51)\end{array}$ & $\begin{array}{l}0.0408 \\
(1.00)\end{array}$ & $\begin{array}{l}0.0181 \\
(0.49)\end{array}$ \\
\hline In(CEO tenure) & $\begin{array}{l}-0.0449 \\
(-0.86)\end{array}$ & $\begin{array}{l}-0.0477 \\
(-0.76)\end{array}$ & $\begin{array}{l}-0.0370 \\
(-0.71)\end{array}$ & $\begin{array}{l}-0.0486 \\
(-0.78)\end{array}$ & $\begin{array}{l}-0.0376 \\
(-0.72)\end{array}$ & $\begin{array}{l}-0.0396 \\
(-0.63)\end{array}$ & $\begin{array}{c}0.0347 \\
(-0.66)\end{array}$ \\
\hline In(CEO compensation) & $\begin{array}{c}-0.0069 \\
(-3.01)^{\star * *}\end{array}$ & - & - & - & - & - & - \\
\hline In(option compensation) & - & $\begin{array}{c}0.0225 \\
(7.93)^{\star \star \star}\end{array}$ & - & $\begin{array}{c}0.0219 \\
(7.71)^{\star \star \star}\end{array}$ & - & $\begin{array}{c}0.0159 \\
(5.26)^{\star \star \star}\end{array}$ & - \\
\hline $\begin{array}{l}\text { Option compensation } \\
\text { as a fraction of } \\
\text { total compensation }\end{array}$ & - & - & $\begin{array}{c}0.1099 \\
(8.76)^{\star \star \star}\end{array}$ & - & $\begin{array}{c}0.0976 \\
(7.78)^{\star \star \star}\end{array}$ & - & $\begin{array}{c}0.0843 \\
(6.64)^{\star * *}\end{array}$ \\
\hline R-squared (adjusted) & $10.5 \%$ & $28.4 \%$ & $42.2 \%$ & $29.7 \%$ & $42.7 \%$ & $29.5 \%$ & $42.5 \%$ \\
\hline
\end{tabular}


Table 3

Regression Results Differentiating between Pressure-Sensitive and Pressure-Insensitive Institutional Investors

Variations of the following regressions are estimated.

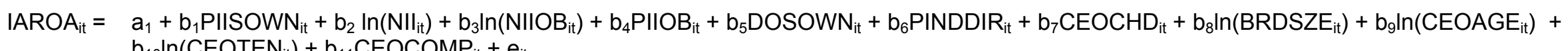
$b_{10} \ln \left(\right.$ CEOTEN $\left._{i t}\right)+b_{11} C E E O C O M P ~_{\text {it }}+e_{i t}$

where, IAROA $_{i t}=$ the industry-adjusted ROA for firm i in year t, PIISOWN = the fraction of institutional investor stock ownership, (variations include: fraction of total institutional investor stock ownership, fraction of pressure-insensitive institutional investor stock ownership), Nil ${ }_{i t}=$ the number of institutional investors holding stock in the firm, (variations include: total number of institutional investors holding stock, number of pressure-insensitive institutional investors holding stock), $\mathrm{NIIOB}_{\mathrm{it}}=$ institutional investors on the board of directors, (variations include: total number of institutional investors on the board, number of pressure-insensitive institutional investors on the board), $\mathrm{PIOB}_{\text {it }}=$ fraction of institutional investors on the board, (variations include: fraction of institutional investors on the board, fraction of pressure-insensitive institutional investors on the board), DOSOWN $\mathrm{N}_{\mathrm{it}}=$ the fraction of director and officer stock ownership, PINDDIR $R_{\text {it }}=$ the fraction of independent outside directors on the board, $C E O C H D_{i t}=$ dummy variable equal to 1 if

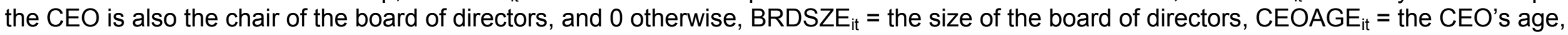
$\mathrm{CEOTEN}_{\mathrm{it}}=$ the CEO's tenure, and CEOCOMP ${ }_{\text {it }}=$ the CEO's compensation, (variations include: natural log of CEO compensation in the form of options, CEO compensation in the form of options/total compensation). t-values are in parentheses.

\begin{tabular}{|c|c|c|c|c|c|c|}
\hline Variable & Regression 1 & Regression 2 & Regression 3 & Regression 4 & Regression 5 & Regression 6 \\
\hline Intercept & $\begin{array}{l}-0.0903 \\
(-0.53)\end{array}$ & $\begin{array}{l}-0.0378 \\
(-0.24)\end{array}$ & $\begin{array}{l}-0.1254 \\
(-0.72)\end{array}$ & $\begin{array}{l}-0.0683 \\
(-0.43)\end{array}$ & $\begin{array}{l}-0.1189 \\
(-0.74)\end{array}$ & $\begin{array}{l}-0.1158 \\
(-0.67)\end{array}$ \\
\hline $\begin{array}{l}\text { Fraction of shares } \\
\text { owned by pressure- } \\
\text { insensitive investors }\end{array}$ & $\begin{array}{l}0.0135 \\
(1.91)^{*}\end{array}$ & $\begin{array}{l}0.0135 \\
(1.89)^{*}\end{array}$ & & & $\begin{array}{l}0.0377 \\
(2.61)^{\star \star \star}\end{array}$ & $\begin{array}{l}0.0426 \\
(2.76)^{\star \star \star}\end{array}$ \\
\hline $\begin{array}{l}\text { Fraction of shares } \\
\text { owned by pressure- } \\
\text { sensitive investors }\end{array}$ & & & $\begin{array}{l}0.0124 \\
(1.96)^{*}\end{array}$ & $\begin{array}{l}0.0124 \\
(1.94)^{*}\end{array}$ & $\begin{array}{l}0.0022 \\
(0.70)\end{array}$ & $\begin{array}{l}0.0042 \\
(0.21)\end{array}$ \\
\hline $\begin{array}{l}\text { In(Number of pressure- } \\
\text { insensitive investors) }\end{array}$ & $\begin{array}{l}0.0155 \\
(2.78)^{\star \star \star}\end{array}$ & $\begin{array}{l}0.0132 \\
(2.88)^{\star \star \star}\end{array}$ & & & $\begin{array}{l}0.0139 \\
(2.24)^{\star \star}\end{array}$ & $\begin{array}{l}0.0197 \\
(3.24)^{\star \star \star}\end{array}$ \\
\hline $\begin{array}{l}\text { In(Number of pressure- } \\
\text { sensitive investors) }\end{array}$ & & & $\begin{array}{l}0.0012 \\
(0.33)\end{array}$ & $\begin{array}{l}0.0030 \\
(0.86)\end{array}$ & $\begin{array}{l}0.0059 \\
(0.96)\end{array}$ & $\begin{array}{l}0.0050 \\
(0.82)\end{array}$ \\
\hline $\begin{array}{l}\text { In(Number of pressure- } \\
\text { insensitive institutional } \\
\text { investors on board) }\end{array}$ & $\begin{array}{l}-0.0356 \\
(-1.26)\end{array}$ & $\begin{array}{l}-0.0189 \\
(-0.73)\end{array}$ & & & $\begin{array}{l}0.0093 \\
(0.31)\end{array}$ & $\begin{array}{l}0.0124 \\
(0.43)\end{array}$ \\
\hline
\end{tabular}




\begin{tabular}{|c|c|c|c|c|c|c|}
\hline $\begin{array}{l}\text { In(Number of pressure- } \\
\text { sensitive institutional } \\
\text { investors on board) }\end{array}$ & & & $\begin{array}{l}-0.0066 \\
(-0.32)\end{array}$ & $\begin{array}{l}-0.0122 \\
(-0.63)\end{array}$ & $\begin{array}{l}-0.0107 \\
(-0.41)\end{array}$ & $\begin{array}{l}-0.0097 \\
(-0.35)\end{array}$ \\
\hline $\begin{array}{l}\text { Fraction of board } \\
\text { comprised of pressure- } \\
\text { insensitive investors }\end{array}$ & $\begin{array}{l}0.0732 \\
(0.19)\end{array}$ & $\begin{array}{l}0.4728 \\
(1.43)\end{array}$ & & & $\begin{array}{l}0.0964 \\
(0.26)\end{array}$ & $\begin{array}{l}0.0902 \\
(0.24)\end{array}$ \\
\hline $\begin{array}{l}\text { Fraction of board } \\
\text { comprised of pressure- } \\
\text { sensitive investors }\end{array}$ & & & $\begin{array}{l}0.2099 \\
(0.82)\end{array}$ & $\begin{array}{l}0.2772 \\
(1.16)\end{array}$ & $\begin{array}{l}0.3878 \\
(1.16)\end{array}$ & $\begin{array}{l}0.3186 \\
(0.97)\end{array}$ \\
\hline $\begin{array}{l}\text { Fraction of firm owned } \\
\text { by directors plus } \\
\text { executive director }\end{array}$ & $\begin{array}{l}0.0834 \\
(1.50)\end{array}$ & $\begin{array}{l}0.0799 \\
(1.48)\end{array}$ & $\begin{array}{l}0.0740 \\
(1.32)\end{array}$ & $\begin{array}{l}0.0678 \\
(1.24)\end{array}$ & $\begin{array}{l}0.0791 \\
(1.41)\end{array}$ & $\begin{array}{l}0.0704 \\
(1.37)\end{array}$ \\
\hline $\begin{array}{l}\text { Independent outside } \\
\text { directors as fraction of } \\
\text { total board }\end{array}$ & $\begin{array}{l}0.0820 \\
(3.44)^{\star * *}\end{array}$ & $\begin{array}{l}0.0774 \\
(3.48)^{\star * *}\end{array}$ & $\begin{array}{l}0.0694 \\
(2.89)^{* * *}\end{array}$ & $\begin{array}{l}0.0660 \\
(2.96)^{* * *}\end{array}$ & $\begin{array}{l}0.0712 \\
(3.12)^{\star * *}\end{array}$ & $\begin{array}{l}0.0793 \\
(3.64)^{* * *}\end{array}$ \\
\hline $\begin{array}{l}\text { CEO/Chair duality } \\
\text { dummy }\end{array}$ & $\begin{array}{l}-0.0129 \\
(-1.42)\end{array}$ & $\begin{array}{l}-0.0092 \\
(-1.04)\end{array}$ & $\begin{array}{l}-0.0141 \\
(-1.52)\end{array}$ & $\begin{array}{l}-0.0095 \\
(-1.06)\end{array}$ & $\begin{array}{l}-0.0076 \\
(-0.86)\end{array}$ & $\begin{array}{l}-0.0082 \\
(-0.91)\end{array}$ \\
\hline $\ln$ (board size) & $\begin{array}{l}-0.0278 \\
(-1.49)\end{array}$ & $\begin{array}{l}-0.0144 \\
(-0.81)\end{array}$ & $\begin{array}{l}-0.0198 \\
(-0.97)\end{array}$ & $\begin{array}{l}-0.0025 \\
(-0.13)\end{array}$ & $\begin{array}{l}-0.0105 \\
(-0.54)\end{array}$ & $\begin{array}{l}-0.0089 \\
(-0.71)\end{array}$ \\
\hline In(CEO age) & $\begin{array}{l}0.0374 \\
(0.93)\end{array}$ & $\begin{array}{l}0.0154 \\
(0.42)\end{array}$ & $\begin{array}{l}0.0517 \\
(1.27)\end{array}$ & $\begin{array}{l}0.0268 \\
(0.72)\end{array}$ & $\begin{array}{l}0.0228 \\
(0.61)\end{array}$ & $\begin{array}{l}0.0243 \\
(0.66)\end{array}$ \\
\hline $\ln ($ CEO tenure $)$ & $\begin{array}{l}-0.0345 \\
(-0.56)\end{array}$ & $\begin{array}{l}-0.0393 \\
(-0.76)\end{array}$ & $\begin{array}{l}-0.0489 \\
(-0.78)\end{array}$ & $\begin{array}{l}-0.0431 \\
(-0.82)\end{array}$ & $\begin{array}{l}-0.0442 \\
(-0.84)\end{array}$ & $\begin{array}{l}-0.0404 \\
(-0.78)\end{array}$ \\
\hline In(option compensation) & $\begin{array}{l}0.0173 \\
(5.85)^{\star * *}\end{array}$ & & $\begin{array}{l}0.0131 \\
(4.94)^{\star \star \star}\end{array}$ & & $\begin{array}{l}0.0919 \\
(3.66)^{\star \star \star}\end{array}$ & \\
\hline $\begin{array}{l}\text { Option compensation as } \\
\text { fraction of total } \\
\text { compensation }\end{array}$ & & $\begin{array}{l}0.0837 \\
(6.64)^{\star * *}\end{array}$ & & $\begin{array}{l}0.1030 \\
(8.32)^{\star * *}\end{array}$ & & $\begin{array}{l}0.1207 \\
(8.76)^{\star \star \star}\end{array}$ \\
\hline R-square (adjusted) & $37.6 \%$ & $43.9 \%$ & $24.0 \%$ & $35.7 \%$ & $36.9 \%$ & $41.3 \%$ \\
\hline
\end{tabular}

* Significant at better than the $10 \%$ level.

** Significant at better than the $5 \%$ level.

*** Significant at better than the $1 \%$ level 


\section{Table 4: Regressions allowing Interaction between explanatory variables}

Dependent variable: Industry-adjusted ROA (IAROA)

\begin{tabular}{|c|c|c|}
\hline Explanatory Variable & Regression 1 & Regression 2 \\
\hline Intercept & $\begin{array}{l}-0.1456 \\
(-0.63)\end{array}$ & $\begin{array}{l}-0.0959 \\
(-0.38)\end{array}$ \\
\hline $\begin{array}{l}\text { Fraction of shares owned by pressure-insensitive } \\
\text { investors }\end{array}$ & $\begin{array}{l}0.0929 \\
(1.85)^{*}\end{array}$ & $\begin{array}{l}0.0635 \\
(1.94)^{*}\end{array}$ \\
\hline In(Number of pressure-insensitive investors) & $\begin{array}{l}0.0433 \\
(2.39)^{\star *}\end{array}$ & $\begin{array}{l}0.0247 \\
(2.45)^{\star *}\end{array}$ \\
\hline $\begin{array}{l}\text { In(Number of pressure-insensitive institutional } \\
\text { investors on board) }\end{array}$ & $\begin{array}{l}0.0043 \\
(0.25)\end{array}$ & $\begin{array}{l}0.0036 \\
(0.15)\end{array}$ \\
\hline $\begin{array}{l}\text { Fraction of board comprised of pressure-insensitive } \\
\text { investors }\end{array}$ & $\begin{array}{l}0.0713 \\
(0.28)\end{array}$ & $\begin{array}{l}0.0533 \\
(0.66)\end{array}$ \\
\hline $\begin{array}{l}\text { Fraction of firm owned by directors plus executive } \\
\text { director }\end{array}$ & $\begin{array}{l}0.0599 \\
(1.47)\end{array}$ & $\begin{array}{l}0.0736 \\
(1.55)\end{array}$ \\
\hline $\begin{array}{l}\text { Independent outside directors as fraction of total } \\
\text { board }\end{array}$ & $\begin{array}{l}0.0612 \\
(2.67)^{\star \star \star}\end{array}$ & $\begin{array}{l}0.0789 \\
(3.31)^{\star \star *}\end{array}$ \\
\hline CEO/Chair duality dummy & $\begin{array}{l}-0.0137 \\
(-1.34)\end{array}$ & $\begin{array}{l}-0.0107 \\
(-1.02)\end{array}$ \\
\hline $\ln$ (board size) & $\begin{array}{l}-0.0368 \\
(-0.94)\end{array}$ & $\begin{array}{l}-0.0225 \\
(-0.86)\end{array}$ \\
\hline $\ln (\mathrm{CEO}$ age $)$ & $\begin{array}{l}0.0515 \\
(0.75)\end{array}$ & $\begin{array}{l}0.0434 \\
(0.75)\end{array}$ \\
\hline $\ln (\mathrm{CEO}$ tenure $)$ & $\begin{array}{l}-0.0401 \\
(-0.86)\end{array}$ & $\begin{array}{l}-0.0458 \\
(-1.32)\end{array}$ \\
\hline In(option compensation) & $\begin{array}{l}0.0204 \\
(4.83)^{\star \star *}\end{array}$ & \\
\hline $\begin{array}{l}\text { Option compensation as fraction of total } \\
\text { compensation }\end{array}$ & & $\begin{array}{c}0.1364 \\
(5.72)^{\star * \star}\end{array}$ \\
\hline $\begin{array}{l}\text { Interaction: Pressure-insensitive share ownership } \times \\
\text { director \& executive share ownership }\end{array}$ & $\begin{array}{l}0.0075 \\
(1.99)^{\star *}\end{array}$ & $\begin{array}{l}0.0060 \\
(1.87)^{*} \\
\end{array}$ \\
\hline $\begin{array}{l}\text { Interaction: Pressure-insensitive share ownership } \times \\
\text { independent outside directors as fraction of total } \\
\text { board }\end{array}$ & $\begin{array}{l}0.0080 \\
(2.49)^{\star \star}\end{array}$ & $\begin{array}{l}0.0071 \\
(2.55)^{\star \star}\end{array}$ \\
\hline $\begin{array}{l}\text { Interaction: Pressure-insensitive share ownership } \times \\
\text { In(Option compensation) }\end{array}$ & $\begin{array}{l}0.0029 \\
(3.81)^{* * *}\end{array}$ & \\
\hline $\begin{array}{l}\text { Interaction: } \ln \text { (Number of pressure-insensitive } \\
\text { investors }) \times \ln (\text { Option compensation) }\end{array}$ & $\begin{array}{l}0.0016 \\
(2.68)^{* * *}\end{array}$ & \\
\hline $\begin{array}{l}\text { Interaction: Pressure-insensitive share ownership } \times \\
\text { Option compensation as fraction of total } \\
\text { compensation }\end{array}$ & & $\begin{array}{l}0.0100 \\
(3.98)^{\star * *}\end{array}$ \\
\hline $\begin{array}{l}\text { Interaction: In(Number of pressure-insensitive } \\
\text { investors) } \times \text { Option compensation as fraction of } \\
\text { total compensation }\end{array}$ & & $\begin{array}{l}0.0047 \\
(2.71)^{\star * \star}\end{array}$ \\
\hline R-square (adjusted) & $39.2 \%$ & $38.5 \%$ \\
\hline
\end{tabular}

* Significant at better than the $10 \%$ level.

** Significant at better than the 5\% level.

*** Significant at better than the $1 \%$ level 